\title{
BMJ Global Health Beware of the success cartel: a plea for rational progress in global health
}

To cite: Rajkotia Y. Beware of the success cartel: a plea for rational progress in global health. BMJ Glob Health 2018:3:e001197. doi:10.1136/ bmjgh-2018-001197

Handling editor Seye Abimbola

Received 27 September 2018 Accepted 27 September 2018

Check for updates

(C) Author(s) (or their employer(s)) 2018. Re-use permitted under CC BY-NC. No commercial re-use. See rights and permissions. Published by BMJ.

\section{Correspondence to}

Yogesh Rajkotia, ThinkWell, Washington, District of

Columbia, USA;

yrajkotia@thinkwell.global
By setting ambitious targets, the global health community has played a pivotal role in motivating the world to achieve remarkable improvements in health. Over 21 million additional lives were estimated to have been saved due to the accelerated progress promoted by the Millennium Development Goals. ${ }^{1}$ Most countries have translated global goals into their own targets, with many even incorporating them into their national health plans. Financing instruments (such as development-linked indicators, performance-based financing and development impact bonds) that offer financial rewards in exchange for strong health results have pushed countries to further accelerate progress. Taken together, the collective ambition to improve health has translated into enormous pressure for health systems to achieve targets.

However, we have also seen the ugly side of this-the high stakes, the ambition and the expectation can instil a fear of failure, stifle risk-taking and innovation, and lead to the fabrication of achievement. On the long and difficult road to sustained health improvements, we cannot ignore the political, financial and reputational blowback that countries face when they fail to deliver on ambitious targets. Political promises, national pride, financial reward and job security weigh heavily on politicians and health systems managers. This can create perverse incentives for countries to embellish their reporting.

The problem is further exacerbated in countries that lack transparency of information, freedom of press and democratic rules of engagement. Should we believe Rwanda's claims on poverty reduction, even as experts ${ }^{2}$ have cast doubt on the validity of their data? Should we believe China's self-reported success stories on achieving universal health coverage $^{3}$ and dramatic improvements in key health indicators, ${ }^{4}$ when there are widespread concerns ${ }^{5}$ about the independence of their national statistics? Are Cuba's globally acclaimed health statistics as robust as they self-report, given observations to the contrary? ${ }^{6}$

Or even broader, what self-reported data can we really believe after reading Jerven's damning analysis ${ }^{7}$ of the production of economic data across the African continent? In several traditionally non-aid sectors, such as trade, finance ${ }^{8}$ and nuclear disarmament, robust verification is a basic prerequisite for international cooperation. So, in the foreign aid sector, why is there less scrutiny-and even defense-of data and stories that are almost too good to be true, as the $\mathrm{IMF}^{9}$ and DFID $^{10}$ did in Rwanda?

Unfortunately, aid agencies-not just country governments-are also driven to be complacent partners in the 'success cartel'. This is, in part, because aid agencies believe their survival relies on convincing their political leadership that taxpayer funds are making an outsized difference and fulfilling foreign policy objectives. Those of us who have worked in aid agencies understand that these pressures are real, leading them to offer a more generous interpretation of the facts. ${ }^{1112}$ Often, this materialises with overattribution. ${ }^{13}$ For instance, aid agencies regularly claim credit for health progress that is largely attributable to countries' own economic growth and poverty reduction, not foreign assistance. ${ }^{14} 15$ In other cases, we find wilful ignorance. For example, USAID touted unprecedented progress in the education sector of post-Taliban Afghanistan, relying on the Afghani government's doctored statistics to make the claim. ${ }^{16}$ USAID took the inflated numbers at face value-without verificationuntil a watchdog group cried foul. ${ }^{17}$ Similarly, in testimony to US Congress, USAID overstated gains ${ }^{18}$ on the number of primary-age children enrolled in school globally.

And let us not forget that the foreign aid industry is a US $\$ 134.8$ billion competitive market $^{19}$ that employs over 600000 people per year. In today's do-or-die market environment, development contractors (NGOs, 
for-profit, non-profit organisations) cannot afford to report poor results. Not surprisingly, they tend to conflate marketing with the unbiased reporting of results necessary for rational progress in global health-and they rarely speak to their own failures.

High expectations for fast progress on persistent and complex health and development challenges have greater consequences than embellished data-it creates a rigid environment in which people are unwilling to take risks and learn from failure. With the stakes as high as they are, it is less risky to import a hyped-up model from another country, regardless of whether it truly 'worked', than to create a home-grown solution. In other words, the fear of failure, instilled by the success cartel, is one of the key reasons for why there is such little innovation in the health development sector.

In a system in which all actors-aid agencies, their implementing partners and recipient countries-face enormous pressure to demonstrate wild success, how can we move towards a more rational, innovation-promoting and accountable environment? To get started, we recommend that they:

1. Recognise that politics, not achievements, drive donor funding in global health. Multilateral and bilateral funding agencies must conquer the irrational fear that funding cuts will result from anything less than eye-popping success. While the threat of funding cuts is real, cuts are often not based on results, but on the political climate. For example, Trump's 'America First' budget proposed steep cuts in foreign assistance due to ideology, not poor performance on targets. Similarly, the UK has considered cutting foreign aid, not because of project performance but due to 'domestic needs and national debt' ${ }^{20}$ Once past this fear, aid agencies can begin to relax their own practices of defunding projects that are not hitting unrealistically set targets. Instead, they can focus on promoting rational development progress.

2. Set targets aspirationally, not dogmatically. As we move away from funding fears, we should also move away from our previous patterns ${ }^{21}$ of chastising those who did not achieve global targets, even when their progress is aligned with historical trends in achievements. Instead, a more pragmatic understanding should view global targets as aspirational ${ }^{22}$-intended to rally governments and civil society to focus their energies on social development.

3. Celebrate and even reward intelligent failure. As described by Edmondson, ${ }^{23}$ not all failures are created equal. Failures arising from deviance, inattention or process inadequacy are unacceptable. But there are praiseworthy failures too-intelligent failures arising from exploration and experimentation in our often uncertain environments. There have been some attempts to create forums to highlight failure, such as self-organised Fail Festivals, ${ }^{24}$ but these are largely ad hoc and small scale. To truly transform the perverse incentives of risk aversion and data embellishment, global health must deeply integrate the celebration of appropriate failure into all aspects of its cycles-from funding appropriation to results evaluation.

4. Require public access to national data as a prerequisite for foreign cooperation. Many global health practitioners and researchers have experienced first-hand how challenging it can be to access national data. Shrouded under the veil of national sovereignty, countries often refuse to release their data for public consumption. This can make it impossible for civil society and independent researchers to verify and replicate their claims. Countries, possibly facilitated by WHO, should urgently sign a pact committing to release national data and its corresponding analysis. Foreign aid providers should focus on building the verification and replication capacity of civil society and independent researchers, preferably within countries themselves. Under no circumstances should the global health community herald countries or models as 'success stories' unless the data and analysis behind those claims are freely available for public scrutiny.

The global health community must actively work to change its operating culture. In our own capacities as individual actors-whether as researchers or practitioners-we must stop operating from a place of scarcity, job insecurity and funding fears; we must learn to push back on rose-coloured reporting; and we must promote a culture that celebrates intelligent failure. By working with integrity, we can begin to break open the 'success cartel' in favour of real and realistic progress in global health.

Acknowledgements The author thanks Leah Breen and Jennifer Deist for their support in drafting this editorial

Funding The authors have not declared a specific grant for this research from any funding agency in the public, commercial or not-for-profit sectors.

Competing interests None declared.

Patient consent Not required.

Provenance and peer review Commissioned; internally peer reviewed.

Data sharing statement № additional data are available.

Open access This is an open access article distributed in accordance with the Creative Commons Attribution Non Commercial (CC BY-NC 4.0) license, which permits others to distribute, remix, adapt, build upon this work non-commercially, and license their derivative works on different terms, provided the original work is properly cited, appropriate credit is given, any changes made indicated, and the use is non-commercial. See: http://creativecommons.org/licenses/by-nc/4.0

\section{REFERENCES}

1. McArthur J, Rasmussen K. How successful were the Millennium Development Goals? Brookings, 2017. Available from:https:// www.brookings.edu/blog/future-development/2017/01/11/howsuccessful-were-the-millennium-development-goals/ [cited 15 Aug 2018].

2. Ansoms A, Marijnen E, Cioffo G, et al. Statistics versus livelihoods: questioning Rwanda's pathway out of poverty. Rev Afr Polit Econ 2017;44:47-65.

3. Yu H. Universal health insurance coverage for 1.3 billion people: what accounts for China's success? Health Policy 2015;119:1145-52.

4. Xinhua News Agency. Chinese life expectancy rises to 76.7 years. China Daily, 2018. Available from:http://www.chinadaily.com.cn/a/ 
201806/13/WS5b2107a8a31001b825721b30.html [cited 15 Aug 2018].

5. Bernanke B, Olson P. China's transparency challenges. Brookings, 2016. Available from:https://www.brookings.edu/blog/ben-bernanke/ 2016/03/08/chinas-transparency-challenges/ [cited 15 Aug 2018].

6. Berdine G, Geloso V, Powell B. Cuban infant mortality and longevity: health care or repression? Health Policy Plan 2018;33:755-7.

7. Jerven M. Poor numbers: how we are misled by African development statistics and what to do about It. Ithaca, London: Cornell University Press, 2013.

8. Armstrong C, Guay W, Mehran $\mathrm{H}$. The role of financial reporting and transparency in corporate governance. Economic Policy Review 2016:107-26.

9. Agutamba K. We have no doubt in Rwanda's poverty figures-says IMF chief. The New Times, 2015. Available from:https://www. newtimes.co.rw/section/read/194120 [cited 15 Aug 2018].

10. Germain N. Rwanda accused of manipulating poverty statistics. France 24, 2015. Available from:https://www.france24.com/en/ 20151102-rwanda-accused-manipulating-poverty-statistics [cited 15 Aug 2018].

11. Mumtaz Z, Ferguson A, Bhatti A, et al. Learning from failure? Political expediency, evidence, and inaction in global maternal health. Soc Sci Med 2017.

12. Mumtaz Z, Ellison GTH, Ferguson A, et al. A call for transparency in the evaluation of global maternal health projects. The Lancet 2016;388:461.

13. Nordland R. U.S Aid Program Vowed to Help 75,000 Afghan Women Watchdog Says It's a Flop. The New York Times, 2018. Available from:https://www.nytimes.com/2018/09/13/world/asia/afghanistanwomen-usaid.html [cited 24 Sept 2018].

14. Acemoglu D, Robinson J. Why foreign aid fails - and how to really help Africa. The Spectator, 2014. Available from:https://www. spectator.co.uk/2014/01/why-aid-fails/ [cited 24 Sept 2018].

15. Radelet S. Once more into the breach: does foreign aid work? Brookings, 2017. Available from:https://www.brookings.edu/blog/ future-development/2017/05/08/once-more-into-the-breach-doesforeign-aid-work/ [cited 24 Sept 2018].

16. Myre G. Afghan schools: is the success story exaggerated? NPR, 2015. Available from:https://www.npr.org/sections/thetwo-way/2015/ 06/18/415353782/afghan-schools-is-the-success-story-exaggerated [cited 15 Aug 2018].

17. Igoe M. Watchdog casts doubts on key USAID Afghanistan achievement, 2015. Available from:https://www.devex.com/news/ watchdog-casts-doubts-on-key-usaid-afghanistan-achievement86374 [cited 15 Aug 2018].

18. Greenberg J. USAID head overshoots gains on getting more kids into school. Politifact, 2016. Available from:https://www.politifact. com/global-news/statements/2016/mar/17/gayle-smith/usaid-headovershoots-gains-getting-more-kids-scho/ [cited 15 Aug 2018].

19. Perry A. The bloated, arrogant aid industry won't let Africa go without a fight. The Telegraph, 2015. Available from:https://www. telegraph.co.uk/news/worldnews/africaandindianocean/11890227/ The-bloated-arrogant-aid-industry-needs-to-let-Africa-go.html [cited 15 Aug 2018].

20. BBC. Developing countries warned UK could cut foreign aid. BBC News, 2018. Available from:https://www.bbc.com/news/uk42686947

21. Easterly W. How the Millennium Development Goals are unfair to Africa. World Development, 2009. Available from:https://www. sciencedirect.com/science/article/pii/S0305750X08001022?via\% 3Dihub

22. New York Times Editorial Board. An ambitious development agenda from the UN. The New York Times, 2015. Available from:https:// www.nytimes.com/2015/09/28/opinion/an-ambitious-developmentagenda-from-the-un.html [cited 15 Aug 2018].

23. Edmonson A. Strategies for learning from failure. Harvard Business Review, 2011. Available from:https://hbr.org/2011/04/strategies-forlearning-from-failure [cited 15 Aug 2018].

24. Fail Festival. Available from:http://failfestival.org/ [cited 15 Aug 2018]. 